\title{
ANALISIS DEREPLIKASI UNTUK IDENTIFIKASI SENYAWA ANTIBAKTERI SPONGE Axinella sp. DARI PERAIRAN KEPULAUAN KARIMUNJAWA
}

\author{
Hedi Indra Januar"), Cherie Motti*), Dianne Tapiolas ${ }^{* *}$, dan Anthony D. Wright ${ }^{* * *}$ )
} \begin{abstract}
ABSTRAK
Riset ini bertujuan untuk mengidentifikasi senyawa antibakteri pada Axinella sp. yang diambil dari kepulauan Karimunjawa dengan metode dereplikasi menggunakan LCMS (Liquid Chromatography Mass Spectrometer) dan FT-MS (Fourier Transfer Mass Spectrometer). Data pola spektra massa dari LC-MS menunjukkan adanya tiga senyawa terbrominasi yang mungkin memiliki bioaktivitas antibakteri. Analisis massa akurat (limit kesalahan di bawah 20 ppm) menggunakan FT-MS menemukan bahwa ketiga senyawa tersebut memiliki monoisotop negatif (M-H) pada $\mathrm{m} / \mathrm{z} 321,9931$ [senyawa (a)]; $\mathrm{m} / \mathrm{z} 383,9089$ [senyawa (b)]; dan $\mathrm{m} / \mathrm{z} 385,9249$ [senyawa (c)]. Analisis komposisi kimia dari besaran massa tersebut yang menggunakan Elemental Composition Calculator menemukan bahwa komposisi kimia dari ketiga senyawa tersebut adalah $\mathrm{C}_{11} \mathrm{H}_{10} \mathrm{~N}_{5} \mathrm{O}_{2} \mathrm{Br}(\mathrm{a}), \mathrm{C}_{11} \mathrm{H}_{9} \mathrm{~N}_{5} \mathrm{OBr}_{2}(\mathrm{~b})$, dan $\mathrm{C}_{11} \mathrm{H}_{11} \mathrm{Br}_{2} \mathrm{~N}_{5} \mathrm{O}$ (c). Penelusuran struktur kimia yang didasarkan pada komposisi tersebut di database MarinLit 2008 (Database struktur kimia senyawa-senyawa dari biota laut) menemukan bahwa ketiga senyawa tersebut merupakan hymeniadisine (a), 3-bromohymenialdiside (b), dan dibromophakelin (c).
\end{abstract}

ABSTRACT: Dereplication analysis for identification of antibacterial compounds in Axinella sp. sponges from Karimunjawa Islands Waters By: Hedi Indra Januar, Ekowati Chasanah, Cherie Motti, Dianne Tapiolas and Anthony D. Wright

This research was aimed to identify the antibacterial compounds in Axinella sp. harvested from Karimunjava islands waters by dereplication analysis using LC-MS (Liquid Chromatography Mass Spectrometer) and FT-MS (Fourier Transfer Mass Spectrometer). The mass spectra pattern of LC-MS showed that there were three brominated compounds which might have antibacterial properties. Accurate mass determination (error limit below 20 ppm) by FT-MS found that those three compounds had negative monoisotope (M-H)- at $\mathrm{m} / \mathrm{z} 321.9931$ [compound (a)]; $\mathrm{m} / \mathrm{z} 383.9089$ [compound (b)]; and $\mathrm{m} / \mathrm{z} 385.9249$ [compound (c)]. Chemical composition analysis of these mass by Elemental Composition Calculator found that the chemical formula of those three compounds were $\mathrm{C}_{11} \mathrm{H}_{10} \mathrm{~N}_{5} \mathrm{O} \mathrm{Br}$ (a), $\mathrm{C}_{11} \mathrm{H}_{9} \mathrm{~N}_{5} \mathrm{OBr}$ (b) and $\mathrm{C}_{11} \mathrm{H}_{11} \mathrm{Br}_{2} \mathrm{~N}_{5} \mathrm{O}$ (c). Based on these compositions, chemical structures searched using MarinLit 2008 database (database on chemical structures of marine organisms compounds) found that those three compounds were suggested as hymeniadisine, 3-bromohymenialdiside and dibromophakelin respectively.

KEYWORDS: Axinella sp., antibacterial, hymeniadisine, 3-bromohymenialdiside, dibromophakelin, dereplication analysis

\section{PENDAHULUAN}

Pada penelitian sebelumnya (Januar et al., 2006) diketahui bahwa sponge Axinella sp. dari Karimunjawa memiliki bioaktivitas antibakteri yang cukup baik, yaitu pada ekstrak awalnya memiliki daya antibakteri sebesar lima puluh persen dari daya antibakteri yang dimiliki oleh senyawa standar kloramfenikol. Berdasarkan tingginya bioaktivitas sampel ini maka penelitian untuk mengetahui senyawa antibakteri yang dikandungnya sangat potensial karena sifat resistensi bakteri yang terus meningkat.
Secara umum senyawa metabolit sekunder dari biota Axinella sp. telah diketahui, antara lain senyawasenyawa golongan terpenoid, siklopeptida, polieter, sterol, dan komponen terbrominasi (Yalçýn, 2007). Lebih lanjut, berdasarkan Dembitsky \& Tolstikov (2003), diketahui bahwa komponen antimikroba yang seringkali ditemukan pada biota ini merupakan senyawa golongan pirol alkaloid terbrominasi. Komponen natural terbrominasi atau terhalogenasi sejak lama telah diidentifikasi sebagai senyawa antibakteri yang sangat kuat, seperti dikemukakan oleh Kelly et al. (2003). Berdasarkan literatur tersebut

\footnotetext{
7. Peneliti pada Balai Besar Riset Pengolahan Produk dan Bioteknologi Kelautan dan Perikanan, DKP

*) Peneliti pada Australian Institute of Marine Science

...) Peneliti pada College of Pharmacy - University of Hawaii at Hilo
} 
maka terdapat kemungkinan bahwa senyawa antibakteri yang terdapat dalam sampel Axinella sp. dari Karimunjawa ini juga merupakan senyawa golongan terbrominasi. Akan tetapi tidak tertutup kemungkinan terdapat senyawa aktif lain atau baru pada sampel ini. Suatu spesies sponge dari lokasi tertentu dapat memiliki komposisi kimiawi berbeda dengan sponge yang diambil dari lokasi lainnya. Contohnya adalah variasi jenis cembranoids dari karang lunak Sarcophyton dan Nephthea sp. dari lingkungan yang berbeda (Januar et al., 2009). Menurut Pawlink (1993), oleh karena beberapa senyawa aktif bersifat sebagai sistem pertahanan biota produsen, maka interaksi ekologis yang berbeda dapat menyebabkan perbedaan komposisi senyawa bahan alami yang dieksresikan. Oleh karena itu, riset untuk mengidentifikasi struktur senyawa Axinella sp. dari Karimunjawa tetap penting dilaksanakan untuk mengetahui jenis senyawa aktif. Selain itu, informasi bioaktivitas dan struktur senyawa aktif dapat diketahui secara utuh sehingga dapat dipergunakan sebagai dasar studi lanjutan.

Identifikasi senyawa kimia bahan alami pada umumnya dilakukan dengan metode purifikasi untuk mendapatkan senyawa murni, baru dilanjutkan dengan identifikasi secara spektroskopis. Selain memerlukan waktu lama dan mahal, repurifikasi senyawa yang sama seringkali terjadi. Oleh karena itu, identifikasi senyawa aktif dari biota yang telah banyak tereksplorasi seperti Axinella sp. dapat dilakukan menggunakan metode dereplikasi. Dereplikasi adalah metode identifikasi pada tahapan sedini mungkin. Keunggulan analisis dereplikasi ini dibandingkan metode purifikasi-identifikasi adalah mampu mendapatkan identitas senyawa aktif secara cepat tanpa melewati tahapan analisis yang panjang (Cordell \& Shin, 1999). Selain itu, repurifikasi terhadap senyawa yang telah diketahui juga dapat dihindari. Namun, kelemahan metode ini adalah tidak mendapatkan bentuk murni senyawa aktif untuk uji kimia atau bioasai lanjutan. Oleh karena itu, metode ini baik diterapkan untuk analisis kualitatif di tahapan awal identifikasi senyawa aktif dari bahan alami. Contoh analisis dereplikasi yang sering dilaksanakan pada biota sponge adalah analisis dereplikasi senyawa sitotoksik aaptamin dan turunannya dari sponge ordo Hadromerida (Calcul et al., 2003). Oleh karena terdapat secara luas spesies ordo tersebut, maka analisis dereplikasi sangat efektif untuk menghindari terjadinya replikasi purifikasi senyawa aaptamin dan turunannya yang telah diketahui.

Hal ini mendasari dilaksanakannya penelitian ini, yang bertujuan untuk mengidentifikasi komponen aktif pada biota Axinella sp. yang berasal dari perairan Karimunjawa menggunakan metode dereplikasi spektroskopi massa. Penerapan metode ini dipilih karena senyawa target merupakan komponen bahan alam terbrominasi yang memiliki ion massa khas pada spektra massa. Penelitian ini menerapkan kombinasi hasil dari dua alat spektrometer massa yaitu instrumentasi LC-MS (Liquid chromatography Mass Spectrometer) untuk detektor massa resolusi rendah pada tahapan identifikasi awal dan FT-MS (Fourier Transfer-Mass Spektrometer) untuk detektor massa resolusi tinggi untuk mendapatkan rumus molekul senyawa target. Menurut Chin et al. (2006), analisis dereplikasi menggunakan spektroskopi massa LC-MS merupakan hal yang efektif untuk menghemat waktu dan beban kerja yang timbul secara tidak perlu akibat replikasi isolasi senyawa aktif yang telah diketahui. Identitas senyawa aktif didasarkan pada database MarinLit tahun 2008 (Blunt \& Blunt, 2008). Database ini memuat struktur senyawa-senyawa terkini yang berasal dari organisme laut. Penerapan database terkini dalam analisis dereplikasi merupakan hal yang sangat penting agar tidak terjadi kesalahan dalam identifikasi, yaitu senyawa dianggap baru dan belum ditemukan karena database yang digunakan sudah kadaluarsa (Corley \& Durley, 1994). Kombinasi analisis spektroskopi massa dan database terkini, selain dapat mengidentifikasi senyawa aktif dari biota laut secara cepat, model analisis yang dilakukan ini juga dapat bermanfaat sebagai salah satu alternatif yang baik untuk mengidentifikasi senyawa aktif dalam penelitian bahan alam dari biota lainnya.

\section{BAHAN DAN METODE}

\section{Pengambilan Sampel dan Ekstraksi}

Sponge diambil dari ekosistem terumbu karang di perairan Taman Nasional Karimunjawa pada bulan Juni 2004. Perairan Karimunjawa terletak di sebelah utara Pulau Jawa pada posisi $6^{\circ} 50^{\prime}$ Lintang Selatan dan $105^{\circ} 5^{`}$ Bujur Timur. Sampel diambil pada kedalaman 5-15 meter dengan Scuba Diving. Sampel yang diperoleh ditimbang bobotnya lalu dimasukkan ke dalam kantong plastik yang telah berisi larutan metanol teknis.

Seluruh sampel langsung dimaserasi menggunakan $200 \mathrm{~mL}$ pelarut metanol. Setelah 48 jam, pelarut disaring, lalu residu sampel ditambah lagi dengan 200 mL metanol. Hal ini dilakukan sebanyak dua kali hingga total pelarut metanol yang digunakan sebanyak $800 \mathrm{~mL}$. Larutan ini kemudian dievaporasi pada suhu $30^{\circ} \mathrm{C}$ selama kurang lebih dua jam menggunakan alat evaporasi Buchi Rotavapor hingga larutan hampir kering dan tidak dapat diuapkan lagi. Untuk menghilangkan seluruh pelarut, ekstrak dikeringkan dengan pengering beku (freeze dryer) sampai diperoleh ekstrak berbentuk bubuk. 


\section{Analisis LC-MS dan FT-MS}

Sampel ekstrak metanol lalu dilarutkan dengan metanol HPLC grade sehingga menjadi $10 \mathrm{mg} / \mathrm{mL}$, kemudian analisis LC-MS dilakukan dengan menginjeksikan $100 \mathrm{uL}$ larutan dalam sistem instrumentasi Shimadzu 2010A dengan kolom Phenomenex Luna RP-C ${ }_{18}(150 \times 2 \mathrm{~mm})$ yang menggunakan fasa gerak gradien dari $10 \%$ asetonitrilair hingga 100\% asetonitril-air selama 40 menit. Analisis ini dilaksanakan di Laboratorium Instrumentasi Balai Besar Riset Pengolahan Produk dan Bioteknologi Kelautan dan Perikanan. Analisis FT-MS dilakukan dengan menginjeksikan sampel sebanyak $100 \mu \mathrm{g} / \mathrm{mL}$ pada FT-MS Bruker BioApex 47e Fourier Transform lon Cyclotron Resonance Mass Spectrometer. Analisis ini dilakukan di Laboratorium BAF-1 Australian Institute of Marine Science. Oleh karena keterbatasan jumlah sampel, maka pada analisis tidak dilaksanakan pengulangan pengamatan. Ketiadaan pengulangan pengamatan umum dilakukan pada determinasi jenis senyawa bioaktif dari bahan alami karena analisis hanya melaksanakan identifikasi secara kualitatif.

\section{Determinasi Senyawa}

Proses determinasi rumus molekul dilakukan dengan menggunakan perangkat lunak Elemental Composition Calculator (Antolasic, 2005) terhadap data massa akurat hasil analisis FT-MS. Hasil rumus molekul yang mungkin dari program tersebut dikomparasi terhadap database elektronik MarinLit 2008, yaitu database yang memuat berbagai struktur kimia senyawa-senyawa dari biota laut, untuk menelusuri senyawa dengan berat molekul target.

\section{HASIL DAN BAHASAN}

Analisis LC-MS terhadap ekstrak metanol memberikan kromatogram seperti pada Gambar 1.

Gambar 1 memperlihatkan hasil analisis sampel pada detektor yang berbeda yaitu UV-PDA (Ultraviolet- Photo diode array) pada panjang gelombang 200$800 \mathrm{~nm}$ (a) dan detektor massa (b). Perbedaan pola kromatogram yang terlihat antara keduanya disebabkan adanya senyawa-senyawa yang tidak menyerap sinar UV-Vis karena tidak memiliki gugus kromofor (gugus penyerap sinar) yang kuat. Walaupun tidak terbaca di spektra UV, senyawa-senyawa tersebut akan dapat terionisasi di spektrometer massa sehingga terbaca pada spektra massa. Spektra di Gambar 1 juga menunjukkan bahwa terdapat ekstrak uji mengandung dua kelompok komponen yang memiliki nilai kepolaran cukup jauh. Kelompok pertama dengan puncak pada kromatogram berada di sekitar menit ke $0-5$, sedangkan yang kedua adalah yang berada di sekitar menit ke 27-31. Data spektroskopi massa pada puncak-puncak di area sekitar 0-5 menit menunjukkan konfigurasi pola yang menarik seperti pada Gambar 2.

Gambar 2 memperlihatkan spektra massa $\mathrm{m} / \mathrm{z}$ positif dari sampel ekstrak metanol Axinella $s p$. Spektra puncak massa yang berada sekitar $0-5$ menit ini dapat ditunjukkan dalam tiga puncak senyawa yaitu spektra massa (a), (b), dan (c). Ketiga spektra ini menunjukkan beberapa pola massa dari senyawasenyawa yang spesifik untuk golongan senyawa terbrominasi. Hal tersebut disebabkan oleh kelimpahan isotop brom ${ }^{79} \mathrm{Br}$ dan ${ }^{81} \mathrm{Br}$ di alam yang hampir serupa, sehingga pada senyawa yang memiliki

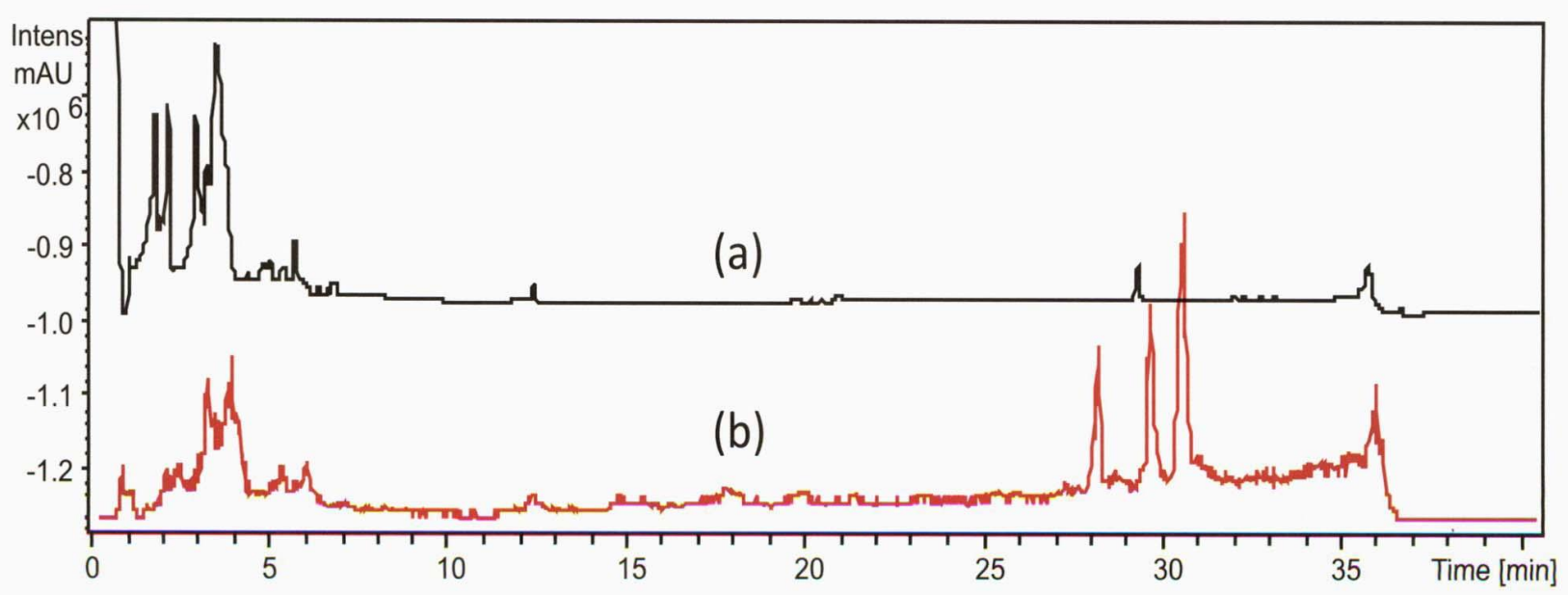

Gambar 1. Kromatogram LC-MS dari ekstrak metanol Axinella sp. dengan (a) detektor UV dan (b) detektor massa

Figure 1. LC-MS chromatogram of methanol extract of Axinella sp. with (a) UV detector and (b) Mass detector 

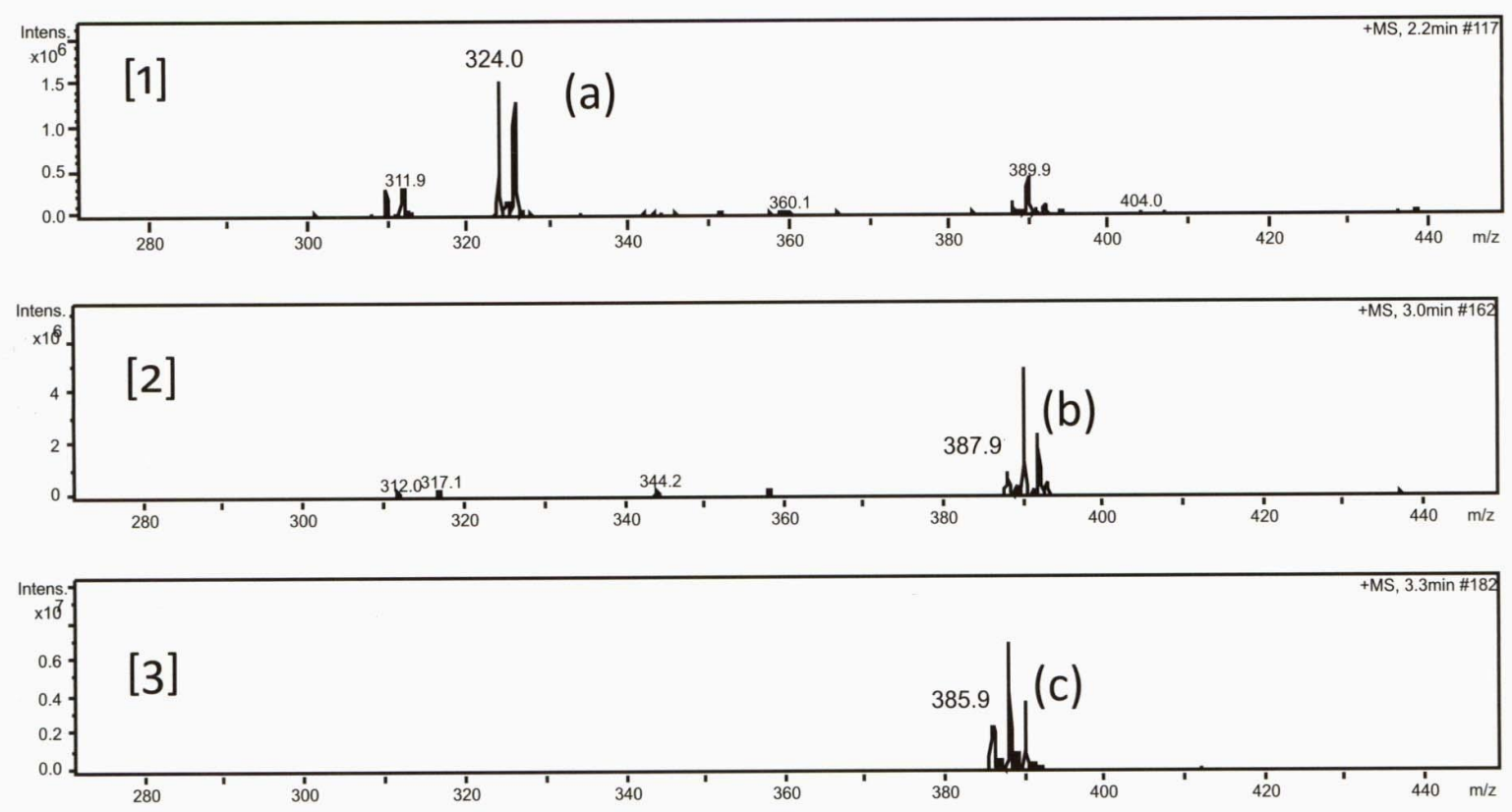

Gambar 2. Spektra massa positif $(\mathrm{M}+\mathrm{H})^{+}$antara menit 0-5 dari kromatogram LC-MS ekstrak metanol Axinella sp., [1] spektra massa senyawa (a), [2] spektra massa senyawa (b), dan [3] spektra massa senyawa (c).

Figure 2. Positive mass spectra $(M+H)^{+}$at 0-5 min. from $L C-M S$ chromatogram of Axinella sp. methanol extract, [1] Mass spectra of compound (a), [2] Mass spectra of compound (b), and [3] mass spectra of compound (c).

satu atom brom, massa yang terbaca di spektra MS akan memberikan puncak kembar yang hampir sama tinggi. Pada senyawa dengan dua atom brom, pola spektra MS akan memperlihatkan tiga puncak, hasil kombinasi antara kedua berat atom brom. Demikian seterusnya, sehingga untuk penentuan cara cepat jumlah atom brom dari suatu pola puncak massa senyawa terbrominasi yang terlihat di spektra massa akan terlihat seperti mengikuti pola deret perhitungan Paskal. Untuk penyederhanaan penyebutan massa dari suatu senyawa yang memiliki beberapa puncak ini, maka identifikasinya dilakukan terhadap monoisotop dari beberapa puncak massa tersebut, yaitu massa yang memiliki nilai $\mathrm{m} / \mathrm{z}$ paling rendah.

Berdasarkan hal tersebut, maka dapat ditentukan bahwa ekstrak metanol sponge ini memiliki sedikitnya satu senyawa dengan satu atom brom yaitu (a) dan dua senyawa dengan dua atom brom yaitu (b) dan (c). Senyawa (a) memiliki monoisotop $\mathrm{m} / \mathrm{z} 324(+)$, senyawa (b) pada $\mathrm{m} / \mathrm{z} 387(+)$, dan senyawa (c) pada $\mathrm{m} / \mathrm{z} 385(+)$. Di kromatogram (a) terlihat adanya beberapa massa lain di sekitar m/z 311 yang merupakan luruhan dari massa senyawa (a) dan sedikit trace dari massa senyawa (b).

Oleh karena komponen senyawa halogen merupakan antiseptik yang kuat, maka dapat diduga bahwa ketiga senyawa ini merupakan sumber bioaktivitas antibakteri dari sampel sponge Axinella sp. dari Karimunjawa ini. Dembitsky \& Tolstikov (2003) serta Kelly et al. (2003) menemukan komponen terbrominasi yang memiliki aktivitas antibakteri. Untuk mendapatkan indentifikasi senyawa terbrominasi berdasarkan spektra massa, dilakukan analisis massa akurat menggunakan FT-MS untuk menentukan rumus molekulnya. Analisis ini langsung dilakukan terhadap ekstrak metanol dengan konsentrasi $100 \mu \mathrm{g} / \mathrm{mL}$. Analisis massa akurat sangat penting pada penentuan rumus molekul suatu senyawa yang tidak diketahui. Hal ini disebabkan untuk hasil yang valid, perbedaan massa yang terobservasi pada hasil instrumentasi dan massa yang dihitung dari rumus molekul yang diusulkan harus di bawah limit kesalahan penentuan massa dari rumus molekul. Besaran limit kesalahan ini dinyatakan dalam mmu (milimass unit) atau ppm (part per million). Limit ini dirumuskan sebagai:

$$
\text { (massa hasil observasi - massa hasil perhitungan) }
$$

ppm atau $\mathrm{mmu}=1 \times 10^{6}$ 
Pada senyawa yang memiliki berat molekul (BM) di bawah 500 dalton, nilai limit kesalahannya harus di bawah 5 ppm, pada senyawa dengan BM di antara 500-2000 dalton limitnya adalah di bawah 10 ppm, sedangkan di atas 2000 dalton limitnya adalah 20 ppm (Anon., 2006). Hal ini yang menyebabkan hasil spektra massa dari instrumentasi LC-MS belum cukup untuk memberikan data determinasi rumus molekul yang cukup kuat untuk determinasi pada analisis kimia bahan alami. Untuk mendapatkan hasil dengan limit kesalahan yang sesuai dengan aturan di atas, maka observasi massa harus dilakukan dengan menggunakan instrumentasi massa yang memiliki tingkat akurasi hingga $10^{-4}$ (empat angka di belakang koma). Oleh karena berat massa pada senyawa terhalogenasi yang akan ditentukan di atas adalah di bawah 500 dalton, maka limit kesalahan akurasinya harus di bawah 5 ppm. Hasil analisis massa akurat terhadap ketiga senyawa dapat dilihat pada Gambar 3.

Dua buah spektra pada Gambar 3 menunjukkan puncak massa negatif $(\mathrm{M}-\mathrm{H})^{-}$senyawa terbrominasi senyawa (a) pada spektra [1] serta tumpang tindih puncak massa senyawa (b) dan (c) pada spektra [2]. Pada spektra [2] terlihat adanya puncak massa pengotor (noise) pada $\mathrm{m} / \mathrm{z} 380,382$, serta 396. Puncak massa senyawa (b) dan (c) terletak di antara m/z 383 dan 390. Puncak lemah yang ada di antaranya tersebut merupakan isotop atom karbon dari masing-masing puncak. Gambar 3 juga memperlihatkan spektra massa akurat negatif $(\mathrm{M}-\mathrm{H})^{-1}$ dari masing-masing senyawa (a), (b), dan (c). Hal ini berbeda dengan pengaturan saat analisis LC-MS yang menelusuri massa positif $(\mathrm{M}+\mathrm{H})^{+}$dari senyawa-senyawa pada sampel. Perbedaan perlakuan ini dilakukan untuk mendapatkan konfirmasi M (massa molekul netral) dari masing-masing senyawa. Hal ini disebabkan karena pada spektra massa positif terdapat banyak kemungkinan, misalnya $(\mathrm{M}+\mathrm{H})^{+},(\mathrm{M}+\mathrm{Na})^{+}$, $(\mathrm{M}+\mathrm{H}+\mathrm{Na})^{+},(\mathrm{M}+\text { pelarut }+\mathrm{H} / \mathrm{Na})^{+}$, atau bahkan ion dimer dari molekul netralnya. Oleh karena itu, analisis ion (M-H)- akan memberikan konfirmasi yang tepat jenis molekul pada spektra massa positif dan juga massa molekul netral dari senyawa target. Penentuan massa molekul netral adalah penambahan satu dari $\mathrm{m} / \mathrm{z}$ ion di spektra negatif atau pengurangan di spektra massa positif sebesar 1 [jenis ion positif $(\mathrm{M}+\mathrm{H})^{+}$], 23 [jenis ion positif $(\mathrm{M}+\mathrm{Na})^{+}$], dan seterusnya. Berdasarkan spektra pada Gambar 3, dapat diperkirakan bahwa monoisotop negatif senyawa (a) adalah pada m/z 321,9931; senyawa (b) $\mathrm{m} / \mathrm{z}$ 383,9089; dan senyawa (c) $\mathrm{m} / \mathrm{z} 385,9249$. Hal ini memberikan konfirmasi terhadap hasil spektra massa positif di Gambar 2 yang merupakan spektra massa positif jenis molekul $(\mathrm{M}+\mathrm{H})^{+}$.

Hasil analisis di atas menunjukkan bahwa hasil analisis massa FT-MS memiliki 4 angka di belakang koma, dibandingkan dengan LC-MS yang hanya memiliki 1 angka di belakang koma. Perbedaan ini memberikan arti yang signifikan terhadap banyaknya
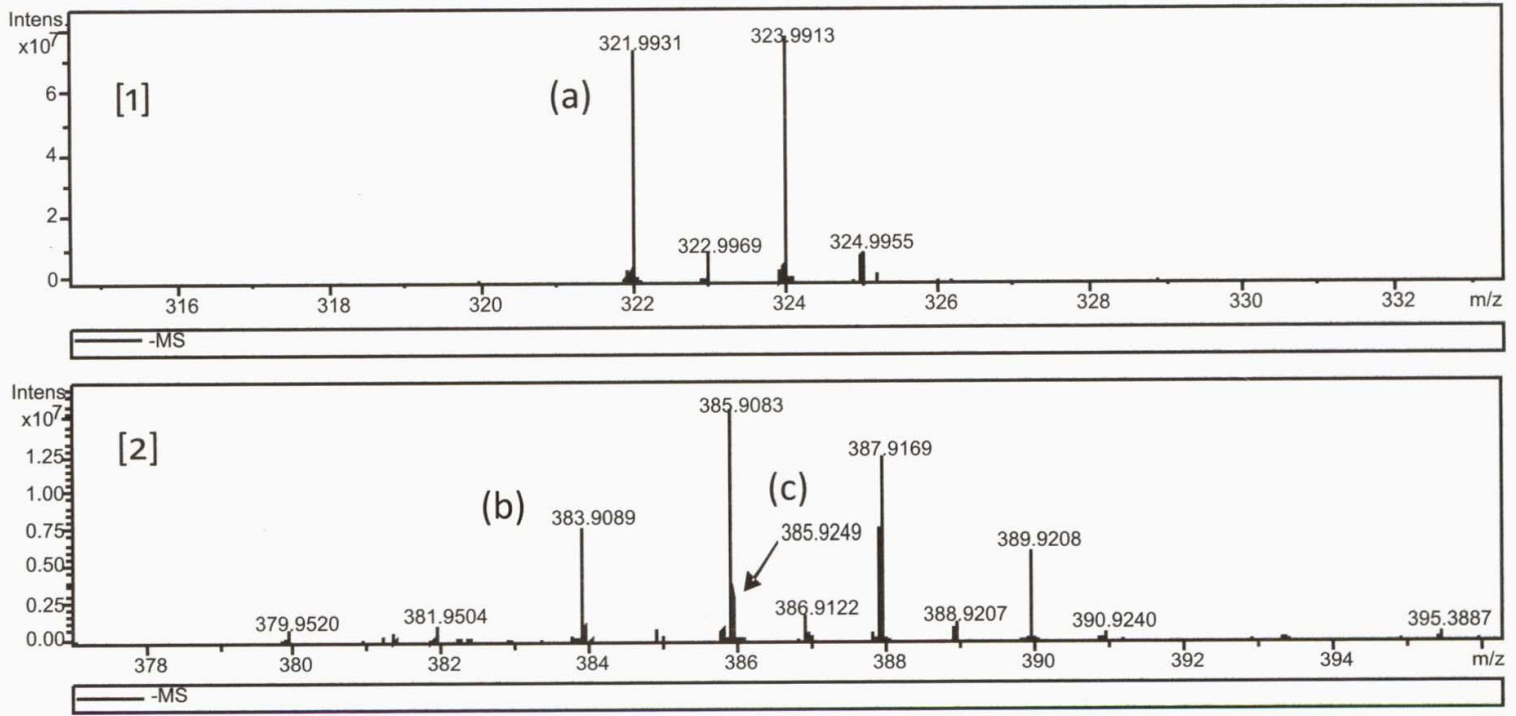

Gambar 3. Spektra massa akurat negatif (M-H) - senyawa terbrominasi pada Axinella sp. yaitu [1] spektra massa akurat senyawa (a) serta [2] adalah spektra massa akurat dari tumpangtindih puncak massa senyawa (b) dan (c).

Figure 3. Negative accurate mass spectra (M-H)- of brominated compounds in Axinella sp. which is [1] accurate mass spectra of compound (a) and [2] accurate mass spectra of overlayed mass peak from compound (b) and (c). 
kombinasi rumus molekul yang memungkinkan. Kalkulasi kemungkinan rumus molekul dengan limit kesalahan akurasi sebesar $2 \mathrm{mmu}$ berdasarkan massa akurat ketiga monoisotop di atas dengan menggunakan program Elemental Composition Calculator yang diprogram oleh Antolasic (2005) dapat dilihat pada Tabel 1.

Jika dilakukan analisis kemungkinan rumus molekul menggunakan metode yang sama analisis identifikasi senyawa bioaktif. Pada beberapa instrumen terbaru yang memiliki harga jauh lebih mahal, fungsi kedua alat ini telah digabungkan dalam satu instrumen yaitu LC-HRMS (Liquid Chromatography - High Resolution Mass Spectrometer) sehingga dapat diperoleh keunggulan dari dua sisi instrumentasi yang dipergunakan dari analisis ini.

Untuk mendapatkan kemungkinan rumus struktur dari ketiga senyawa di atas, data rumus molekul di

Tabel 1. Kemungkinan rumus molekul dari tiga senyawa terbrominasi pada Axinella sp.

Table 1. Molecular formula possibility of three brominated compounds in Axinella sp.

\begin{tabular}{|c|c|c|c|c|c|}
\hline $\begin{array}{l}\text { Senyawa/ } \\
\text { Compound }\end{array}$ & $\begin{array}{l}\text { Monoisotop Ion } \\
\text { (M-H)- Hasil } \\
\text { Observasi/ } \\
\text { Observed } \\
\text { Monoisotope } \\
\text { Ion }(M-H)^{-}\end{array}$ & $\begin{array}{c}\text { Kemungkinan } \\
\text { Rumus Ion } \\
\text { Molekul (M-H)-/lon } \\
\text { Molecular (M-H)- } \\
\text { Formula } \\
\text { Possibility }\end{array}$ & $\begin{array}{c}\text { Kemungkin } \\
\text { Rumus Molekul } \\
\text { Netral (M)/Neutral } \\
\text { Molecular (M) } \\
\text { Formula } \\
\text { Possibility }\end{array}$ & $\begin{array}{c}\text { Kalkulasi } \\
\text { Monoisotop Ion } \\
\left(\mathrm{M}-\mathrm{H}^{)-} / \text {Calculated }\right. \\
\text { Monoisotope of } \\
\text { Ion }(\mathrm{M}-\mathrm{H})^{-}\end{array}$ & $\mathrm{mmu}$ \\
\hline \multirow{2}{*}{ (a) } & \multirow{2}{*}{$321.9931(\mathrm{M}-\mathrm{H})$} & $\mathrm{C}_{10} \mathrm{H}_{13} \mathrm{NO}_{6} \mathrm{Br}^{-}$ & $\mathrm{C}_{10} \mathrm{H}_{14} \mathrm{NO}_{6} \mathrm{Br}$ & 321.9926 & -1.4752 \\
\hline & & $\mathrm{C}_{11} \mathrm{H}_{9} \mathrm{~N}_{5} \mathrm{O}_{2} \mathrm{Br}^{-}$ & $\mathrm{C}_{11} \mathrm{H}_{10} \mathrm{~N}_{5} \mathrm{O}_{2} \mathrm{Br}$ & 321.9940 & 2.6771 \\
\hline \multirow{2}{*}{ (b) } & \multirow{2}{*}{$383.9089(\mathrm{M}-\mathrm{H})$} & $\mathrm{C}_{10} \mathrm{H}_{12} \mathrm{NO}_{5} \mathrm{Br}_{2}^{-}$ & $\mathrm{C}_{10} \mathrm{H}_{13} \mathrm{NO}_{5} \mathrm{Br}_{2}$ & 383.9082 & 1.7634 \\
\hline & & $\mathrm{C}_{11} \mathrm{H}_{8} \mathrm{~N}_{5} \mathrm{OBr}_{2}^{-}$ & $\mathrm{C}_{11} \mathrm{H}_{9} \mathrm{~N}_{5} \mathrm{OBr}_{2}$ & 383.9096 & -1.7192 \\
\hline \multirow{3}{*}{ (c) } & \multirow{3}{*}{$385.9249(\mathrm{M}-\mathrm{H})$} & $\mathrm{C}_{10} \mathrm{H}_{14} \mathrm{NO}_{5} \mathrm{Br}_{2}^{-}$ & $\mathrm{C}_{10} \mathrm{H}_{15} \mathrm{NO}_{5} \mathrm{Br}_{2}$ & 385.9239 & 2.6611 \\
\hline & & $\mathrm{C}_{11} \mathrm{H}_{10} \mathrm{~N}_{5} \mathrm{OBr}_{2}^{-}$ & $\mathrm{C}_{11} \mathrm{H}_{11} \mathrm{~N}_{5} \mathrm{OBr}_{2}$ & 385.9252 & -0.8033 \\
\hline & & $\mathrm{C}_{13} \mathrm{H}_{12} \mathrm{~N}_{2} \mathrm{O}_{2} \mathrm{Br}_{2}^{-}$ & $\mathrm{C}_{13} \mathrm{H}_{13} \mathrm{~N}_{2} \mathrm{O}_{2} \mathrm{Br}_{2}$ & 385.9266 & -4.2832 \\
\hline
\end{tabular}

berdasarkan massa yang diperoleh dari spektra massa LC-MS, maka kombinasi rumus molekul yang mungkin dari tiap massa molekul senyawa (a), (b), dan (c) menjadi sangat banyak. Hal ini merupakan keunggulan utama analisis massa akurat FT-MS jika dibandingkan dengan analisis massa pada LC-MS. Namun, karena pada FT-MS analisis dilakukan tanpa ada pemisahan terlebih dahulu, maka akan sangat sulit jika belum diketahui adanya perkiraan target senyawa yang dituju. Dalam hal ini, LC-MS akan lebih baik. Proses pemisahan yang dilakukan pada bagian kromatografi di LC-MS akan dapat memisahkan suatu senyawa dari senyawa lainnya, sehingga terlihat puncak massa secara tersendiri. Hal ini diperlihatkan dengan hasil massa yang terpisah dari masing-masing senyawa seperti pada Gambar 2, dibandingkan dengan puncak tumpang tindih pada spektra [2] untuk senyawa (b) dan (c) di spektra FT-MS seperti yang terlihat pada Gambar 3. Selain itu, hasil LC-MS sangat berguna untuk memberikan gambaran dan hipotesis awal mengenai jenis molekul target dan penentuan $\mathrm{m} / \mathrm{z}$ target yang akan dilihat pada spektra FT-MS. Oleh karena itu, walaupun beresolusi rendah, analisis LCMS tidak dipisahkan dengan FT-MS. Kombinasi penerapan keduanya sangat baik dilakukan pada
Tabel 1 dibandingkan dengan database elektronik MarinLit (Blunt \& Blunt, 2007). Senyawa (a) memiliki kemungkinan molekul netral (M) $\mathrm{C}_{11} \mathrm{H}_{10} \mathrm{~N}_{5} \mathrm{O}_{2} \mathrm{Br}$ atau $\mathrm{C}_{10} \mathrm{H}_{14} \mathrm{NO}_{6} \mathrm{Br}$. Komparasi terhadap database MarinLit menunjukkan bahwa Axinella sp. hanya memiliki satu kemungkinan rumus struktur terhadap senyawa dengan rumus $\mathrm{C}_{11} \mathrm{H}_{10} \mathrm{~N}_{5} \mathrm{O} \mathrm{Br}$. Selain itu, penelusuran terhadap database tidak menemukan satupun molekul yang memiliki komposisi $\mathrm{C}_{11} \mathrm{H}_{14} \mathrm{NO}_{6} \mathrm{Br}$. Walaupun secara kalkulasi komputasi komposisi molekul di atas adalah mungkin, namun dengan tidak terdapatnya di database, maka kemungkinan besar bahwa konfigurasi tersebut tidaklah lazim terdapat secara alami. Oleh karena itulah, untuk senyawa (a) dapat diperkirakan bahwa rumus molekulnya adalah $\mathrm{C}_{11} \mathrm{H}_{10} \mathrm{~N}_{5} \mathrm{O}_{2} \mathrm{Br}$. Penelusuran terhadap senyawasenyawa yang dihasilkan oleh Axinella sp., diketahui bahwa hanya hymeniadisine yang memiliki konfigurasi seperti di atas. Oleh karena itu, senyawa (a) dapat diperkirakan merupakan senyawa hymeniadisine.

Melalui pola penelusuran yang sama, diketahui bahwa rumus molekul netral senyawa (b) merupakan $\mathrm{C}_{11} \mathrm{H}_{9} \mathrm{~N}_{5} \mathrm{OBr}_{2}$. Hal ini disebabkan karena komposisi molekul $\mathrm{C}_{10} \mathrm{H}_{13} \mathrm{NO}_{5} \mathrm{Br}_{2}$ tidak terdapat di database dengan kemungkinan penyebab yang sama seperti 
pembahasan sebelumnya. Penelusuran lebih lanjut terhadap senyawa-senyawa yang dihasilkan dari Axinella sp. menunjukkan bahwa rumus molekul netral ini hanya memiliki satu kemungkinan, yaitu 3bromohymenialdiside. Untuk senyawa (c) diketahui bahwa rumus molekul netral yang paling mungkin adalah $\mathrm{C}_{11} \mathrm{H}_{11} \mathrm{~N}_{5} \mathrm{OBr}_{2}$, karena database tidak mengenal satupun struktur dengan konfigurasi molekul seperti dua kemungkinan lainnya dengan sebab yang mungkin sama seperti sebelumnya. Penelusuran lebih lanjut menemukan bahwa hanya dibromophakelin yang memiliki konfigurasi molekul seperti di atas yang telah diketahui dihasilkan dari Axinella sp. Ketiga struktur senyawa ini diperlihatkan pada Gambar 4 berikut. cukup sesuai untuk mengidentifikasi hasil analisis dereplikasi.

Model analisis ini akan sangat baik digunakan di tahapan awal untuk mengenali secara cepat senyawasenyawa yang telah tereksplorasi. Selain itu, tingginya sensitivitas spektrometer massa dibandingkan dengan peralatan spektroskopi lainnya juga merupakan suatu keuntungan karena penggunaan sampel yang sedikit sehingga tidak mempergunakan banyak waktu selama preparasi analisis dibandingkan dengan cara lain seperti metode spektroskopi RMI (Resonansi Magnetik Inti). Akan tetapi, kelemahan utama dari model analisis ini adalah ketidakmampuan<smiles>NC1=NC(=O)/C(=C2\CCNC(=O)c3[nH]c(Br)cc32)N1</smiles>

hymeniadisine<smiles>NC1=NC(=O)C(=C2CCNC(=O)c3[nH]c(Br)c(Br)c32)N1</smiles>

3-bromohymenialdiside<smiles>C[C@H]1C[C@H]2C3N=C([Al])NC3n3c(cc(Br)c3Br)C(=O)N12</smiles>

dibromophakelin

(a)

(b)

Gambar 4. Struktur molekul hymeniadisine (a), 3-bromohymenialdiside (b), dan dibromophakelin (c).

Figure 4. Molecular structures of hymeniadisine (a), 3-bromohymenialdiside (b), and dibromophakelin (c).

Penelusuran data massa akurat terhadap database yang didasarkan data identifikasi biologi jenis biota seperti pada metode determinasi senyawa ini berhasil menemukan senyawa bioaktif yang telah diketahui dari Axinella sp. Seperti pada analisis di atas, determinasi massa akurat dapat memberikan rumus molekul senyawa dan kemungkinan strukturnya berdasarkan database MarinLit 2008. Penggunaan berbagai macam database lainnya seperti ChapmanHall, Napralert, Chemical Index, dapat mempengaruhi hasil sehingga terdapat juga kemungkinan menemukan senyawa jenis lain dari yang dikemukakan di atas dengan bobot molekul yang sama namun strukturnya berbeda. Namun, database MarinLit merupakan kumpulan struktur senyawa yang khusus untuk bahan alami biota laut seperti sponge, karang lunak, tunikata dan lainnya, dari berbagai jurnal yang terakreditasi secara internasional. Oleh karena itu, secara subjektif diperkirakan bahwa penggunaan satu jenis database ini pada versinya yang terbaru akan membedakan jenis isomer suatu senyawa, yaitu senyawa yang memiliki rumus molekul sama, namun dengan rumus struktur yang berbeda. Contoh dari senyawa-senyawa ini adalah aaptamin dan isoaaptamin. Kedua senyawa tersebut memiliki rumus molekul yang sama yaitu $\mathrm{C}_{13} \mathrm{H}_{12} \mathrm{~N}_{2} \mathrm{O}_{2}$, sehingga mempunyai puncak yang sama pada spektra massa, yaitu $(\mathrm{M}+\mathrm{H})^{+} 229,0970$. Kesulitan Iainnya adalah keduanya umum dihasilkan oleh biota yang sama. Pembedaan di antara kedua isomer struktur ini hanya mampu dibaca pada spektra hasil instrumentasi RMI. Keterkinian database juga berpengaruh besar terhadap hasil analisis. Sesuai dengan rilis database di akhir tahun 2008, terdapat juga kemungkinan bahwa terdapat senyawa lain dengan massa yang sama dipublikasikan di tahun 2009 ini. Hal ini sulit dihindari walaupun menggunakan tambahan database elektronik yang lain. Pada umumnya update databasedatabase bahan alami elektronik juga akan dipublikasi di akhir tahun. Cara lain yang dapat digunakan agar 
selalu mendapat data senyawa terbaru adalah dengan selalu berlangganan berbagai jurnal, namun cara ini akan sangat mahal. Oleh karena itu, penerapan analisis bahan alami yang optimal adalah uji dilakukan secara bertahap, mulai dari uji spektroskopi massa di tahapan awal (seperti pada penelitian ini) lalu hasilnya ditelusuri pada database elektronik yang sesuai untuk biota target. Jika terdapat kemungkinan senyawa isomer, analisis dilanjutkan dengan uji RMI. Akan tetapi jika setelah kedua tahapan analisis tersebut belum diperoleh identitas dari senyawa target, maka analisis baru dilakukan dengan tahapan purifikasi dan elusidasi lanjutan yang dipandu dengan bioasai.

\section{KESIMPULAN}

Berdasarkan penerapan analisis dereplikasi spektroskopi massa menggunakan LC-MS dan FTMS, diketahui bahwa Axinella sp. dari perairan Karimunjawa memiliki tiga senyawa terbrominasi yaitu hymeniadisine $\left(\mathrm{C}_{11} \mathrm{H}_{10} \mathrm{~N}_{5} \mathrm{O}_{2} \mathrm{Br}\right)$, 3-bromohymenialdiside $\left(\mathrm{C}_{11} \mathrm{H}_{9} \mathrm{~N}_{5} \mathrm{OBr}_{2}\right)$, dan dibromophakelin $\left(\mathrm{C}_{11} \mathrm{H}_{11} \mathrm{Br}_{2} \mathrm{~N}_{5} \mathrm{O}\right)$ yang memiliki daya antibakteri yang baik. Penerapan dereplikasi menggunakan spektroskopi massa yang dilakukan ini merupakan metodologi yang cepat dalam mengidentifikasi senyawa-senyawa alami dari sponge dengan kombinasinya bersama database terkini dari organisme tersebut. Selain itu, model analisis ini dapat bermanfaat sebagai salah satu alternatif yang baik untuk mengidentifikasi senyawa aktif dalam penelitian bahan alami lain.

\section{UCAPAN TERIMA KASIH}

Sebagian besar dukungan finansial dari riset ini berasal dari Aus-Aid Public Sector Linkage Program, Indonesia, Grant ROU 37118. Ucapan terima kasih diucapkan kepada Staf Taman Nasional Kepulauan Karimunjawa, Mulyadi dan Mualim, untuk pengambilan sampel menggunakan SCUBA diving dan Dr. Ekowati Chasanah atas analisis antibakteri yang dilaksanakan pada uji pendahuluan riset ini.

\section{DAFTAR PUSTAKA}

Anonymous. 2006. MS: Elemental composition calculation and their interpretation. Mass Spectrometry - Essay and Tutorial. Jeol USA Inc.
Antolasic, F. 2005. Elemental composition calculator. Wsearch software. www.wsearch.com.au. Diakses tanggal 22 Januari 2008.

Blunt, J.W. and Blunt, D.A. 2008. MarinLit-Marine Literature Database. Version \# vpc13.5. Devised by Munro, M.H.G. and Blunt, J.W. Maintained at various time by Hickford, S.J.H., Vigneswaran, M., Celestine, Unger, R. E., Hu, S. Marine Chemistry Group, Department of Chemistry-University of Caterbury. Christchurch, New Zealand.

Calcul, L., Longeon, A., Mourabit, A.A., Guyor, M., and Bourguet-Kondracki, M-L. 2003. Novel alkaloids of the aaptamine class from an Indonesian marine sponge of the genus Xestospongia. Tetrahedron. 59(34): 6539-6544.

Chin, W.Y., Jones, W.P., Rachman, I., Riswan, S., Kardono, L.B.S., Chai, H.B., Farnsworth, N.R., Cordell, G.A., Swanson, S.M., Cassady, J.M., and Kinghorn, A.D. 2006. Cytotoxic Lignans from the Stems of Helicteres hirsuta Collected in Indonesia. Phytotherapy Research. Phytother. Res. 20: 62-65.

Cordell, G. A. and Shin, Y.G. 1999. Finding the needle in the haystack. The Dereplication of Natural Product Extracts. Pure Appl. Chem. 71(6): 1089 \pm 1094 .

Corley, D.G. and Durley, R.C. 1994. Strategies for database dereplication of natural products. Journal of Natural Products. 57(11): 1484-1490.

Dembitsky, V.M. and Tolstikov, G.A. 2003. Natural Halogenated Alkaloids. Chemistry for Sustainable Development. 11: 451-466.

Januar, H.I., Wikanta, T., Fajarningsih, N.D., and Sugiyono. 2006. A case of study: Antibacterial agent from Axinella sp. and the environmental parameters of its habitat. Proceeding paper and poster presentation at International Seminar and Workshop on Marine Biodiversity, Jakarta, May 17.

Januar, H.I., Chasanah, E., Nielson, J., Motti, C., Tapiolas, D., and Wright, A.D. 2009. Natural products Nephthea and Sarcophyton spp. from Seribu Islands, Indonesia: Is their production related to local pressure from environmental stressors? Proceeding paper and oral presentation at World Ocean Conference, Manado, May 11-14.

Kelly, S.R., Jensen, P.R., Henkel, T.P., Fenical, W., and Pawlik, J.R. 2003. Effects of caribbean sponge extracts on bacterial attachment. Aquatic Microbial Ecology. 31: 175-182.

Pawlink, J.R. 1993. Marine invertebrate chemical defenses. Chem Rev. 93: 1911-1922.

Yalçýn, F.N. 2007. Biological Activities of the Marine Sponge Axinella. Hacettepe University Journal of the Faculty of Pharmacy. 27(1): 47-60. 